\title{
Государи Руси-России и Троице-Сергиева Лавра
}

\author{
badacz niezależny \\ Moskwa, Rosja \\ prot.rostislav@gmail.com
}

протоиерей Ростислав Ярема

rev. R. Yarema, Sovereigns of Ancient Rus-Russia and The Trinity Lavra of St. Sergius, Elpis, 20 2018: 211-219.

ks. R. Yarema, Panowie Starożytnej Rusi-Rosji i Ławra Troicko-Siergijewska, Elpis, 20 2018: 211-219.

\begin{abstract}
The article analyzes the attitude of the sovereigns of Ancient Rus-Russia to The Trinity Lavra of St. Sergius through the prism of the tradition of visiting the monastery by reigning individuals, grand dukes and members of their families. It shows a historical retrospective of the existing tradition, and the level of its significance for understanding the role of the Trinity Monastery of St. Sergius in the state's spiritual and political life.

The Trinity road (the Tsar's road) is seen not only as a path to purification, a way of approaching God, but also as the highest need of reigning individuals in blessing before the most significant events in their personal life and in the state's life, which was largely determined by representatives of the royal house.
\end{abstract}

Streszczenie: W artykule analizowany jest stosunek władców Starożytnej Rusi-Rosji do Ławry Troicko-Siergijewskiej przez pryzmat tradycji zwiedzania klasztoru przez osoby panujące, wielkich książąt i członków ich rodzin. Pokazano historyczną retrospekcję istniejącej tradycji i skalę jej znaczenia dla zrozumienia roli Ławry Troicko-Siergijewskiej w moralnym i politycznym życiu państwa.

Troicka droga (Carska droga) jest postrzegana nie tylko jako droga do oczyszczenia, droga zbliżania się do Boga, ale i jako wyższa potrzeba błogosławieństwa przed najbardziej znaczącymi wydarzeniami w życiu osobistym i w życiu państwa, którą w dużej mierze posiadali przedstawiciele domu panującego.

\begin{abstract}
Аннотация: В статье анализируется отношение государей Руси-России к Троице-Сергиевой Лавре через призму традиции посещения монастыря царствующими особами, великими князьями и членами их семей, показана историческая ретроспектива существовавшей традиции, и уровень ее значимости для понимания роли Троице-Сергиевого монастыря в духовной и политической жизни государства.

Троицкая дорога (Царская дорога) рассматривается не только как путь к очищению, путь приближения к Богу, но и как высочайшая потребность царствующих особ в благословении перед самыми значимыми событиями в личной жизни и в жизни государства, которая во многом определялась представителями царского дома.
\end{abstract}

Keywords: The Holy Trinity-St. Sergius Lavra, Troitskaya (Royal) road, pilgrimage of the prince, tradition of visits, crucial moments, blessing

Słowa kluczowe: Ławra Troicko-Siergijewska, Troicka (Carska) droga, pielgrzymka cesarza, tradycja odwiedzania, kluczowe momenty, błogosławieństwo

Ключевые слова: Троице-Сергиева Лавра, Троицкая (Царская) дорога, государево богомолье, традиция посещений, переломные моменты, благословение

В такой огромной целостности - геополитической, историко-культурной - как Россия существуют, помимо административных, экономических, - эпицентры духовной силы, составляющей внутреннюю опору государства и народа. Определить их можно не по формальным признакам, а по той силе притяжения, которая проявляется в потребности посещать места, где расположены эти центры, в тяготении к ним людей - независимо от социального положения, возраста и других внешних отличий. Для России такими духовными центрами стали Троице-Сергиева лавра, Свято-Введенская Оптина пустынь, Валаам и Соловецкий архипелаг...

Троицкий монастырь среди этих православных святынь занимает место особое. Небольшая монашеская обитель, основанная Варфоломеем (будущим Сергеем Радонежским) и его братом Стефаном, за почти семь веков превратилась в святое для православных место, которое в царской России ежегодно привлекало свыше 300 тысяч паломников, ищущих духовного очищения и благословения Божьего.

История обители связана со многими важными событиями Руси и Российской Империи. Троицкий монастырь является не только свидетелем, но и духовным источником противодействия междоусобицам князей 14 века, направляющих объединение раздробленных Русских земель. Позже, в Смутное время начала 17 в. монастырь сыграл объединяющую роль в борьбе народа против иностранных колонизаторских войск, захвативших и разграбивших Москву.

Важное значение для понимания значимости Троице-Сергиевого монастыря в духовной жизни многих поколений русских людей имеет традиция его посещения царствующими особами, великими князьями и членами их семей. 
Троицкая дорога (ныне Ярославское шоссе) стала для них путем к очищению, потребностью в благословении перед самыми значимыми событиями в их личной жизни и в жизни государства, которая во многом определялась представителями царского дома.

Начала этой традиции положил великий князь Дмитрий Иванович (Донской). Можно только предполагать, почему великий князь, «всех князей русских привожаше под свою волю», ходил на исповедь в обитель к Сергию Радонежскому задолго до Куликовской битвы, ставшей судьбоносным событием для России и определившим всю ее дальнейшую судьбу. Но, без сомнения, полученное из уст Сергея Радонежского благословение и предсказание о победе, вдохновили и придали силы собирателю русских земель перед важнейшим в истории России сражением.

После того, как свершилось пророчество Сергия, Троицкий монастырь обрел еще большую значимость в духовной и политической жизни страны. Это событие стало определяющим для отношений между Лаврой и великокняжеским (царским) двором. Вплоть до XVII столетия русскими правителями совершались ежегодные паломничества в Троице-Сергиеву Лавру, это было священной традицией.

Российские правители чтили Троице-Сергиеву Лавру и ценили её особую духовную атмосферу, а потому приезжали сюда на богомолье и делали многие богатые вклады в монастырь ${ }^{1}$. О царских паломничествах в Сергиеву Лавру после Дмитрия Донского достаточно сведений сохранилось до наших дней в русских летописях в виде кратких записей.

Традицию «государевых богомолий »к Троице в 1432 г. продолжил укреплять внук Дмитрия Донского, Великий князь Московский и Владимирский Василий II (Темный), который в 1439 г. пожаловал монастырю село Сватковское. ${ }^{2}$ Можно только предположить значение общения с игуменом Зиновием и другими священнослужителями Троицкого монастыря Великого князя Василия Второго, который сыграл важную роль в истории православной церкви, отказавшись в 1439 г. принять флорентийскую унию с римско-католической церковью.

Однако роль Троице-Сергиевого монастыря отнюдь не сводилась к матримониальным церемониалам. В Троицком соборе у усыпальницы Сергия Радонежского торжественным «крестоцелованием» скрепляли московские князья договоры и союзы, совершали молебны перед походами и по возвращении из них. Здесь происходили важнейшие для своего времени политические события. В 1442 г. стараниями игумена Зиновия был заключен мирный договор между Василием II и его двоюродным братом - галицким князем Дмитрием Юрьевичем Шемякой. Но уже через шесть лет - в 1446

Вкладная книга Троице-Сергиева монастыря / Изд. подготовили: Е. Н. Клитина, Т. Н. Манушина, Т. В. Николаева. М. Наука. 1987.

2 Лаврская летопись [электронный ресурс] / Свято-Троицкая Сергиева Лавра - Режим доступа: http://stsl.ru/history/ (дата обращения 10.07.2018) г. именно в Троице-Сергиевом монастыре Великий московский князь Василий II был пленен можайским князем Иваном Андреевичем и от имени Дмитрия Шемяки ослеплен...

О перипетиях борьбе за московский престол Дмитрия Шемяки с князем Василием Темным повествует отрывок «Поездка великого князя в Троицкий монастырь» из летописи по «Воскресенскому списку»: «...О великом князи из ы мани и, как пойман бысть князем Иваном Андреевичем у Троици в Сергиеве монастыре в лето $6954(1446)<\ldots>$ И тако начяша князи и с своими съветники безвестно въоружатися и искати подобна времени, како бы изгонити великого князя. Усмотрев же сии таков получей подобен их злому съвету, въсхотевшу великому князю итти и поклонитися Живоначялной Троици и мощем чюдотворца Сергиа: пошедшу же ему и с своими благородными чады, с князем Иваном и с князем Юрьем...»³.

Потребность посетить последнюю обитель великого Сергея Радонежского, видимо, возникала у правителей земли Русской особенно в переломные моменты жизни. Так, судя по летописям и другим источникам, московский великий князь Иван III (1462-1505) незадолго до смерти, осенью 1503 года, совершил поездку в Троице-Сергиев монастырь, Переславль-Залесский, Ростов и Ярославль ${ }^{4}$. Это было богомольное путешествие по святым местам ${ }^{5} 16$ июня 1510 г. Великий князь Василий III посетил Троицкий монастырь и «поставил свещу негасимую у Сергиева гроба» в благодарность за покорение Пскова, из похода на который он возвратился 17 марта. 15 декабря 1513 года великий князь Василий III присутствовал на освящении законченной постройкой надвратной церкви во имя прп. Сергия Радонежского с приделом Василия Парийского в Троице-Сергиевом монастыре ${ }^{6}$. В сентябре 1515 года Василий III «с великою княгинею ездил к Троице в Сергиев монастырь, а оттоле ездил по городам» ${ }^{7}$. В июне 1518 года «благоверный и христолюбивый князь великий Василий благословился у отца своего Варлама митрополита и поехалъ къ Живоначалной Троици въ монастырь преподобнаго Сергия чюдотворца помолитеся и благословитися, хотя поити на свое дело на своего недруга Жихъдимонта короля Полскаго» ${ }^{8}$. Ясно, что Василий III молился о победе над своим врагом. В 1523 г. Василий III побывал в Троицком монастыре перед походом на Казань

\footnotetext{
ПСРЛ. Т. VIII. СПб. 1859.

ПСРЛ. Т. 12. СПб. Изд. Императорской Археологической комиссии. 1901. С. 257-258.

5 Забелин И. Троицкие походы русских царей / И. Забелин. М.: Изд. Императорского Общества истории и древностей российских. 1847. C.3.

6 Иларий, Арсений. Описание славянских рукописей библиотеки Свято-Троицкой Сергиевой лавры / Иларий, Арсений. М. Изд. Императорского Общества истории и древностей российских. 1878. Ч. 2. Отд. 6. С. 225; 12.

7 ПСРЛ. М. Наука. 1965. Т. 30. С. 142.

8 ПСРЛ. - СПб. Изд. Императорской Археологической комиссии. 1904. Т. 13. 1-я пол. С. 29, 21. С. 394.

9 Лаврская летопись [электронный ресурс] / Свято-Троицкая Сер-
} 
Великий князь Василий Ш посещал Троице-Сергиев монастырь в сентябре 1532 г., а ровно через год -21 сентября 1533 г. состоялась его последняя поездка с Еленой Глинской и обоими сыновьями в Троице-Сергиев монастырь. А совсем вскоре после этого - 4 декабря - троицкий иыгумен Иоасаф (Скрипицын) присутствовал на кончине Великого князя Василия III ${ }^{10}$.

Значение, которое придавалось Троице-Сергиеву монастырю великими князьями, становится очевидным из того факта, что его Троицкий собор служил «крестильной» для наследников престола. Так, еще Василий Второй в 1440 г. крестил здесь княжича Иоанна Васильевича - будущего Иоанна III. По известной легенде, рождению у Великого князя Иоанна III и Софии Палеолог сына - княжича Василия - предшествовало явление Софии преподобного Сергия. Вполне понятно, почему именно в Троице-Сергиевом монастыре и был крещен (1479 г.) «чудесно дарованный родителям преподобным Сергием» великий князь Московский Василий III.

Такое же чудесное появление на свет наследника престола связывает и с Иваном Грозным. В сентябре 1529 г. состоялось путешествие Василия III и Елены Глинской в Троицкий монастырь на богомолье о даровании ребенка ${ }^{11}$. Об этом свидетельствует и составитель «Пискаревского летописца» в статье за 1584 г.: «...А пред рождением его, царя Ивана, отец его князь велики Василей Иванович всеа Русии по обещанию своему для бездетства пошел пеш к Троице в Сергиев монастырь молитися с великою княгинею Еленою $<\ldots>$ И прииде на Москву, зача великого князя Ивана и роди в лета 7038 (1530)» ${ }^{12} .4$ сентября 1530 года в Троице-Сергиевом монастыре великий князь крестил своего сына Ивана, родившегося 25 августа этого года ${ }^{13}$. Будущего царя Ивана IV в ходе крещения положили на раку Сергея Радонежского. Позже Иван Грозный крестил в Троцком храме своих сыновей и устроил серебряную раку, в которой покоятся мощи преподобного Сергия.

В Троицкую обитель Иван IV совершил в 1547 г. (25 января) богомольное путешествие вскоре после венчания на царство, а через 20 с небольшим дней (17 февраля) пешее богомольное путешествие вскоре после свадьбы с Анастасией Романовной Захарьиной. Потом в июне 1548 г. - пешее хождение вместе с Великой княгиней Анастасией к Троице ${ }^{14}$.

гиева Лавра - Режим доступа: http://stsl.ru/history/ (дата обращения 10.07.2018)

10 Там же.

11 Лаврская летопись [электронный ресурс] / Свято-Троицкая Сергиева Лавра - Режим доступа: http://stsl.ru/history/ (дата обращения 10.07.2018)

12 ПСРЛ. Т. 34. Постниковский, Пискаревский, Московский и Бельский летописцы. М. Наука. 1978. С. 194.

13 ПСРЛ. Т. 13. 1-я пол. СПб. Изд. Императорской Археологической комиссии. 1904. С. 407.

14 Лаврская летопись [электронный ресурс] / Свято-Троицкая Сергиева Лавра - Режим доступа: http://stsl.ru/history/ (дата обращения 10.07.2018)
Свидетельством особого почитания преподобного Сергия Радонежского Иваном Грозным является его забота об укреплении Троицкого монастыря, куда он приезжал и лично наблюдал за ходом строительства, превратившего монастырь в укрепленную крепость с каменными стенами, сторожевыми башнями, окруженную рвами и надолбами. Монастырские владения были значительно расширены, под его управление был передан Покровский монастырь на Хотькове ${ }^{15}$.

В Троицкий монастырь Иван Грозный уже почти под конец жизни - 6 января 1583 г. - пришел после великой трагедии своей жизни - смерти по его вине сына, царевича Ивана: «И о том поминание о царевиче Иванне плакал и рыдал, и умолял Царь и государь, шесть поклонов в землю челом положил со слезами и рыданием» ${ }^{16}$.

Перед важными событиями московские государи считали обязательным посетить монастырь и получить благословение.

Показателем духовной значимости Троицко-Сергиевского монастыря для Ивана Грозного является то, что он в 1 половине 1552 г. заехал в монастырь для молитвы перед выступлением в поход на Казань, а потом, 27-28 октября - снова посетил обитель на обратном пути из Казани в Москву. Необходимо отметить, что при взятии Казани присутствовал троицкий Келарь Адриан Ангелов. А в мае 1556 г. Иван Грозный также посетил Троицкий монастырь перед отъездом в Серпухов к войску, собранному против крымского хана Девлета. И даже известие о покорении Астрахани царь получил во время богомолья в сентября этого же года в Троицком монастыре ${ }^{17}$

В честь присоединения Казани и Астрахани Иван Грозный заложил в Троице-Сергиевском монастыре Успенский собор по образцу одноименного собора в Московском Кремле. Его освящение состоялось уже после смерти Ивана Грозного - 15 августа 1585 г. в присутствии царя Федора Иоанновича который в 1586 г. пожаловал Троице-Сергиеву монастырю губную грамоту, а в 1591 г. посетил Троице-Сергиев монастырь на праздник Пятидесятницы ${ }^{18}$.

Пожалуй, самым большим радетелем Троицкого монастыря был царь Борис Годунов, который делал огромные пожертвования обители. Еще будучи боярином, в 1594 г. он передал в Троице-Сергиев монастырь «колокол большой благовестник, весу в нем 625 пуд.». Годуновский колокол, названный «Лебедь», сохранился до настоящего времени. В 1598 г. царь Борис Годунов приехал в Троицкую обитель и «приложил к чюдотворному местному образу живоначальные Троицы пелену большую» («Жемчужная пелена») ${ }^{19}$, а затем

\footnotetext{
15 Лаврская летопись [электронный ресурс] / Свято-Троицкая Сергиева Лавра - Режим доступа: http://stsl.ru/history/ (дата обращения 10.07.2018)

16 Там же.

17 Там же.

18 Там же.

19 Вкладная книга Троице-Сергиева монастыря, М., 1987. С. 29.
} 
подарил Троицкому монастырю драгоценный оклад к образу «Троицы» и колокол, который впоследствии был назван в его честь «Годунов» ${ }^{20}$. В 1603 г. государь подарил монастырю большой благовестный колокол, и даже сам сопровождал привоз его в обитель ${ }^{21}$.

Судьба одного из самых умных и полезных для Отечества правителей России, который способствовал учреждению патриаршества на Руси и обеспечению независимости Русской православной церкви от константинопольского патриарха, завершилась трагически для него и его семьи, а Троицкий монастырь стал их усыпальницей.

В 1606 г., когда после того, как царским престолом завладел Лжедмитрий I, царь Василий Иванович Шуйский приказал торжественно перенести останки Годунова и убитых членов его семьи в Троицкий монастырь, где их заново захоронили в западной паперти Успенского собора ${ }^{22}$. Василий Шуйский продолжил традицию русских царей и в 1906 г. приезжал в Троице-Сергиев монастырь, а в 1609 г. пожаловал обители землю на окраине Москвы, за Земляным городом, по берегам реки Неглинной (впоследствии Троицкая слобода и Троицкое Сухаревское подворье) $)^{23}$.

Первый государь из династии Романовых, Михаил Федорович практически сразу же после избрания на царствование - 23 апреля 1613 г. - поехал в Троице-Сергиев монастырь, где его торжественно встречала братия во главе с архимандритом Дионисием ${ }^{24}$ и где он провел неделю «укрепляясь молитвою к подвигу великого служения» ${ }^{25}$. В знак признание заслуг монастыря в защите Москвы от оккупантов в 1616 г. царь Михаил Федорович пожаловал Троице-Сергиеву монастырю на городок Радонеж с пустошами и разоренный поляками Махрищский монастырь ${ }^{26}$.

А через 10 лет после восшествия на престол «государь Царь и Великий Князь Михайло Феодорович всеа Русии пожаловал прислал в дом живоначальные Троицы двери царские, на створех Благовещение пречистые Богородицы и евангелисты чеканные с финифтом, сень и столбцы обложены серебром чеканом золочены». Царские врата и сегодня украшают центральную часть иконостаса Троицкого собора.

В 1626 г. царь Михаил Федорович приложил к иконе Святой Троицы Троице-Сергиева монастыря три

\footnotetext{
20 Лаврская летопись [электронный ресурс] / Свято-Троицкая Сергиева Лавра - Режим доступа: http://stsl.ru/history/ (дата обращения 10.07.2018)

21 Вкладная книга Троице-Сергиева монастыря. М., 1987. Л. 55 об, 56.

22 Лаврская летопись [электронный ресурс] / Свято-Троицкая Сергиева Лавра - Режим доступа: http://stsl.ru/history/ (дата обращения 10.07.2018)

23 Там же.

24 Там же.

25 Историческое описание Свято-Троицкия Сергиевы лавры, составленное по рукописным и печатнымисточникам профессором А. В. Горским. 1841. Ч.1, с. 121

26 Лаврская летопись [электронный ресурс] / Свято-Троицкая Сергиева Лавра - Режим доступа: http://stsl.ru/history/ (дата обращения 10.07.2018)
}

драгоценные цаты «с привесными плащами», которые ныне хранятся в лаврской ризнице ${ }^{27}$ В $1641-1643$ гг. по указу царя Михаила Федоровича была произведена опись имущества Троице-Сергиева монастыря, хранящаяся в ризнице ${ }^{28}$.

Через три года после восшествия на царский престол, в 1648 г. в Троице-Сергиев монастырь на праздник памяти преподобного Сергия дважды приезжал второй самодержец всея Руси из династии Романовых - Алексей Михайлович ${ }^{29}$. В апреле-мае 1650 г. он совершил пешее хождение в Троице-Сергиев монастырь на Троицын день ${ }^{30}$, а 25 сентября 1671 г. «молился в дому пресвятыя и живоначальныя Троицы на праздник великого чюдотворца Сергия» ${ }^{31}$.

Существует довольно подробное описание «Троицкого похода» (19-30 сентября 1675 г.) царя Алексея Михайловича Романова, составленное секретарем австрийского посольства в России Адольфом Лизеком. За несколько дней до поездки царь отправил в монастырь подьячего или другого сановника с грамотой к архимандриту и братии монастыря, в которой сообщал о своем скором прибытии в обитель. По приказу царя начали поспешный ремонт дороги, по которой государь собирался совершить паломничество. Подобные работы проводились, как правило, монастырскими крестьянами, которые жили близ «царской дороги».

По обыкновению в день отъезда царь приходил в Успенский собор, где его встречал патриарх, а хор пел многолетие. Царь прикладывался к иконам и мощам московских святителей, после чего патриарх благословлял его и свиту, кропил их святою водою. Получив благословение, царь выходил из собора, садился на коня или в карету и прощался с народом. По словам А. Лизека, в тот день собралась почти вся Москва, чтобы проводить Алексея Михайловича в поход. Людьми была заполнена не только площадь, но и крыши ближайших домов и церквей. Лизек также упоминает, что на церемонии присутствовал персидский посол со всею свитою. Так начинался поход к Троице.

Особое внимание в описании автор уделяет церемониалу и торжественности проводов царя. С самого утра воевода с полутора тысячами лучших московских стрельцов готовил путь для царя. Впереди шествия везли большую пушку, которую сопровождали два заряжающих. У одного была секира, а другой нес копье, которое венчал двуглавый орел с фитилем в когтях. По бокам двигалась фаланга секироносцев в красной суконной одежде, за ними шли знаменосцы, трубачи и барабанщики. Это шествие остановилось в поле, где в ожидании царя было построено 14-тысячное войско отряд, который посылали впереди всей колонны, чтобы

\footnotetext{
27 Вкладная книга Троице-Сергиева монастыря. М., 1987. С. 30.

28 Лаврская летопись [электронный ресурс] / Свято-Троицкая Сергиева Лавра - Режим доступа: http://stsl.ru/history/ (дата обращения 10.07.2018)

29 Там же.

30 Там же.

31 Вкладная книга Троице-Сергиева монастыря. М., 1987. С. 31.
} 
подготовить место для остановки царя. С этим отрядом передвигались 30 и более обозов с продовольствием, оружием и деньгами для пожертвований, а также повозки с царскими вещами: платьем, бельем, посудой и прочими предметами царского быта.

С особым величием и торжественностью ехала украшенная золотом и серебром царская карета, возглавляемая кавалькадой из 62 всадников и запряженная шестью рослыми жеребцами. По сторонам кареты шли личные охранники царя с пищалями, и слуги.

Карета царицы была больше царской и наряднее, ее везли 12 лошадей. За ней ехала карета царевича, запряженная четырьмя маленькими лошадьми (возможно, это были пони), ее сопровождали четыре карлика. После карет царской семьи следовали бояре, окольничие, думные дворяне, стольники и слуги.

Как было сказано, по пути царь делал остановки для отдыха. Первая такая остановка на пути из Москвы в Лавру в походе 1675 года была сделана близ Троицкой заставы «У Креста» или Крестовской заставы. Недалеко от этого места было раскинуто множество палаток и шатров. Шатер для государя был обтянут тонкой тканью алого цвета с вышитыми на ней узорами, а изнутри - обит дорогими серебряными и «золотными» тканями. Сменив платье и отдохнув, царь отправлялся в дорогу. Следующая остановка была в селе Алексеевском, или Тайнинском, потом были Большие Мытищи, села Пушкино ${ }^{32}$ и Братовщина. Последним местом остановки царя Алексея Михайловича было село Воздвиженское, куда царь прибыл 24 сентября.

Когда царь делал остановки в населенных пунктах, жители с хлебом и солью, а иногда и с богатыми подношениями, встречали его. Царь одаривал людей деньгами и приказывал хорошо их накормить, щедро раздавал милостыню беднякам и нищим.

Как уже было сказано, накануне праздника Преподобного Сергия Радонежского царь останавливался в селе Воздвиженском, где его ждали архимандрит монастыря, келарь и казначей с иконами и просфорами. Они били челом, приглашая царя на службу в собор. Приняв приглашение, царь отпустил их, повелев ожидать своего прибытия.

За четыре версты до Троице-Сергиевой Лавры царь менял платье, и оставшийся путь по традиции преодолевал пешком. В воротах Лавры его встречал архимандрит с братией, поднося ему монастырский поcox - знак того, что он передавал царю свою власть как патриарху. После этого царь направлялся в Троицкий собор, где слушал ектинию, и, приложившись к мощам преподобного Сергия, отправлялся в свои покои.

\footnotetext{
32 Первое документальное упоминание о селе Пушкино относится к 1499 году («писцовая книга князя В.И. Голенина на митрополичье село Пушкино Московского уезда»). Название появилось во второй половине XIV века, когда местностью по реке Уче владел боярин Григорий Александрович Морхинин, по прозвищу Пушка (ум. 1380) - основатель боярского рода Пушкиных (к которому принадлежал поэт Александр Сергеевич Пушкин). Имя боярина связано с производством пушек, он управлял существовавшим здесь древним заводом для отливки пушек.
}

О том, где именно находились в Лавре покои Алексея Михайловича Романова, сведений не сохранилось, но можно предположить, что они располагались в теремах, построенных еще при Иване Грозном, на месте которых в конце XVII века были возведены каменные Царские чертоги. При архимандрите Тихоне Писареве с восточной стороны дворца был пристроен учительский корпус и столовая. Е. Голубинский, описывая Царские чертоги ссылается на монастырское описание Лавры, где говорится: «Царские чертоги, каменные о двух ярусах на 40 саженях длины и девяти сажен ширины и со стенами: расписанные снаружи разными красками наподобие шахмат и убранные в пристойных местах. А особливо столбы у окон изразцовыми разными фигурами: с южной стороны оных имеются два парадные для всхода великолепные крыльца с фронтонами, на коих арматура и короны позлащенные, обновлены в 1775-м году, и во всю линию (здания) открытая на столбах из белого камня галерея, с которой открывается прекрасный вид».

Со слов монастырских служителей, еще заставших помянутые «всходы» в чертоги, в монастырской летописи записано так: «На том месте, где ныне находятся два входа в академический сад, против колокольни и против Успенского собора (и против крылец у чертогов) начинались каменные всходы или лестницы, с каменным же балюстрадом, прерываемые площадкою посередине и оканчивающиеся также площадкою... В бывшем дворце, а теперешнем ректорском корпусе помещается домовая академическая церковь в честь Покрова Божией Матери, занимая восточную четверть верхнего этажа дворца».

Благодаря приведенным источникам, мы имеем представление о Царских чертогах, которые были построены при Алексее Михайловиче, а древнейшая их часть - при Иване Грозном, и до него. Часть царских чертогов могла быть построена еще при жизни Сергия Радонежского, поскольку «каменные всходы и лестницы, прерываемые площадками посередине» - это является древнейшим приемом русского зодчества и напоминает Золотое крыльцо в самой древней части Кремлевского дворца, у Грановитой палаты.

Во время пребывания в монастыре в царских покоях, известно, что царь посещал монастырские богослужения, был в монастырской больнице, где раздавал милостыню. В день праздника, после службы он совершил пышную трапезу и пожаловал деньгами монастырскую братию. В ответ монахи подносили ему изделия из дерева, выполненные руками монастырской братии. По окончании праздника царь отправился в Москву, прибыв туда 30 сентября. На подъезде к Москве его встречало духовенство для сопровождения в Успенский собор. Там патриарх благословлял царя, окропляя его и бояр святой водою. После чего царь проследовал во дворец.

Вот так по исторической записи мы получили достаточно подробное представление о том, как проходи- 
ли Троицкие походы Алексея Михайловича и русских князей и царей... ${ }^{33}$.

Судьба Троице-Сергиевского монастыря тесно переплелась с судьбой российских самодержцев, а нередко и определяла ход русской истории.

В 1682 г. во время Стрелецкого бунта в монастыре около двух месяцев укрывались юные цари Иван и Петр. История, как известно, не знает сослагательного наклонения. Но даже представить трудно, как сложилась бы судьба страны, если бы до юных царей добрались восставшие во главе с князем И.А. Хованским стрельцы... Сюда же, в Троице-Сергиевскую обитель, сбежал из подмосковного села Преображенского царь Петр, спасаясь от стрельцов, верных царевне Софье, возжелавшей стать единоличной царицей. В тот же день в монастырь прибыли мать, жена и сестра царя Петра, а также стрелецкий Сухарев полк ${ }^{34}$, потом приехали высшая знать и духовенство.

Петр утвердил Троицкий монастырь первой «царской» обителью и щедро вознаградил. В монастыре по желанию Петра I построили Трапезную палату с церковью Сергия, каменный дворец (Царские чертоги), надвратную церковь Иоанна Предтечи, Надкладезную часовню, Настоятельские покои.

Петр I всегда носил с собой иконку преподобного Сергия Радонежского. Однако процесс реформирования и устройство Северной столицы требовали значительного количества средств, вследствие чего Петр I «позаимствовал» у Троицкого монастыря огромную сумму в 400 тыс. руб. А запрет возводить каменные здания где бы то ни было, кроме Санкт-Петербурга, приостановил строительство в монастыре до середины XVII в.

Конец XVII века стал апофеозом экономического могущества и политического влияния Троице-Сергиевского монастыря. Но и в годы царствования трех российских императриц: Анны Иоанновны, Елизаветы Петровны и Екатерины II он оставался крупнейшим религиозным центром и богатейшим монастырем с более 100 тыс. крепостных, с владениями в 15 губерниях, 150 подвориями в 45 городах и 13 приписными монастырями. Еще в 1739 г. Анна Иоанновна подписала указ «о бытии Троице-Сергиеву монастырю первостепенным» монастырем Российской империи».

Особенно любила Троицкий монастырь императрица Елизавета, которая в 1742 г. присвоила ему высший монастырский ранг «лавры». Она часто устраивала пешие богомольные «походы», которые занимали не один месяц, потому что за день она проходила всего 2-3 версты, после чего отправлялась в карете во дворец. Назавтра карета привозила ее к

\footnotetext{
33 Троицкий поход царя Алексея Михайловича [электронный ресурс] / Православный портал «Покров», Материал подготовлен редакцией журнала «Встреча» - Режим доступа: http://pokrov.pro/troickij-poxodcarya-alekseyamixajlovicha/ (дата обращения 10.07.2018)

34 Лаврская летопись [электронный ресурс] / Свято-Троицкая Сергиева Лавра - Режим доступа: http://stsl.ru/history/ (дата обращения 10.07.2018)
}

тому месту, откуда и забрала, и Елизавета шла дальше еще пару верст...

Императрица Екатерина II и ее сын Павел I тоже с удовольствием посещали Троице-Сергиеву лавру, а Екатерина II даже написала житие Сергия Радонежского. В 1782 году она пожаловала обители статус города и назвала его Сергиев Посад.

В 1742 г. в Троице-Сергиевой лавре открылась Духовная семинария, а с 1814 г. туда перевели из Москвы Духовную академию, что обеспечило лавре до наших дней статус одного из крупнейших центров религиозного образования в России. В 1750 г. в Свято-Троицкую Сергиеву Лавру был доставлен царь-колокол весом более четырех тысяч пудов. В этом участвовало три тысячи человек.

В 1801 г. после кончины императора Павла I митрополиту Платону были переданы императорская карета и трость с набалдашником, украшенным бриллиантами и изумрудами. 15 сентября 1801 г. состоялась коронация Александра Павловича, совершенная Платоном, как первенствующим архиереем Церкви. А уже 24 сентября - император Александр I прибыл в Лавру, чуть позже за ним последовала вся императорская семья.

Важное отметить малоизвестное обстоятельство, свидетельствующее о значимости Троице-Сергиевской лавры: в 1811 г. Наполеон обратился к митрополиту Платону с предложением о соединении Православной и Католической Церквей. Завоевателю всей Европы было ведомо, в чем состоит внутренний духовный стержень непобедимой России. Когда французские войска подступили к Москве, митрополит Платон, находясь в это время в Махрищском монастыре, благословил наместника Троице-Сергиевой лавры совершить крестный ход вокруг Сергиева Посада для избавления города и обители от французов со словами: «А Бонапарту с ватагою своей не сдобровать и в Сергиевой обители не бывать». После вторжения французских войск в Россию в 1812 г. по поручению митрополита Платона наместник Лавры преподнес императору Александру древний образ преподобного Сергия, написанный на гробовой доске святого. Лавра пожертвовала для нужд армии огромные деньги - 70000 руб. ассигнациями, 2500 руб. серебром и 5 пудов серебра в слитках. Епископ Августин благословил московское ополчение, разрешив записываться в него ученикам духовных училищ. Прекрасно понимая значимость духовного начала, объединившего народ в борьбе с французскими захватчиками, император Александра I в 1816 г приехал в Москву и в тот же день посетил Лавру $^{35}$.

Потребность в приобщении к средоточию этих духовных начал народной жизни притягивали к Троице-Сергиеву монастырю представителей всех сосло-

\footnotetext{
35 Лаврская летопись [электронный ресурс] / Свято-Троицкая Сергиева Лавра - Режим доступа: http://stsl.ru/history/ (дата обращения 10.07.2018)
} 
вий, нередко преодолевавших на пути к святыне немалые расстояния. Мало кому известно, что в 1830 г. в Троице-Сергиеву Лавру совершил пешее паломничество и 16-летний М.Ю. Лермонтов.

Трижды приезжал в Лавру и Император Николай I. Не единожды посещал ее и император Александр II - Освободитель. Известен случай, связанный с обстоятельствами наречения первого сына Императора Александра II великого князя Сергея Александровича. После коронации, которая состоялась в Москве 26 августа 1856, Император и Императрица приехали в Троице-Сергиеву Лавру, где и остановились на ночлег и «у гроба ... Молитвенника и Заступника России, с верою и упованием повергаясь пред нетленными Его останками, дали тайный обет, что если Бог дарует им сына, то нарекут Его Сергием в память и благодарность ему великому Угоднику Божию..» ${ }^{36}$.

Особое отношение российских самодержцев и высшей знати к обители преподобного Сергея Радонежского было обусловлено не только официальной традицией монаршего благодарения за спасение России от польского владычества и за начало царствование династии Романовых. Благоговение перед духовным заступником России выливалось в стремление найти в его святой обители духовную поддержку и просветления в решении важнейших государственных проблем, «точку опоры» в собственном личном мироощущении.

Александр III впервые оказался в Троице-Сергиевой Лавре еще юношей и навсегда сохранил наилучшие чувства к этой обители благочестия. 22 мая 1883 г. Император со свитой выехал по Ярославской железной дороге, вдоль которой, на станциях, крестьяне встречали царский поезд. Архимандрит Товий (Цымбал), наместник Лавры, встречал «смиренного и благоговейного поклонника заветной русской святыни» ${ }^{37}$.

Последней - самой значимой и трагической страницей «исторической связи правящей династии с Троице-Сергиевой Лаврой и ее великим основателем прп. Сергием» стало царствование Николая II, который чаще всех императоров после Петра I посещал Сергиеву обитель - практически при каждом визите из Санкт-Петербурга в Первопрестольную Москву. Глубокую связь последнего императора России с Сергеевой обителью можно выразить словами благоговейное почитание.

После коронационных торжеств 1896 года Государь вместе с супругой и вдовствующей Императрицей Марией Федоровной приезжали в лавру на день Святой Троицы. Митрополит Сергий (Ляпидевский) «поднес Императору и Императрице св. крест, окропил св. водою и произнес речь», в которой подчеркнул

\footnotetext{
36 СТСЛ. 2009, т.4, 1851-1857, с. 257

37 О Высочайшем посещении Лавры Преподобного Сергия государем императором Александром III 22 мая 1883 г. [электронный ресрс] / Свято-Троицкая Сергиева Лавра - Режим доступа: http://stsl. ru/news/all/o-vysochayshem-poseshchenii-lavry-prepodobnogo-sergiyagosudarem-imperatorom-aleksandrom-iii-22-maya (дата обращения 10.07.2018)
}

что «начало обители Преподобнаго Сергия современно было возвышению княжества Московскаго и предшествовало объединению Царства Российскаго, которому она стала служить духовно опорой...».

Устные предания повествуют о посещении в 1905 году Государем и Его Семьей прп. Варнавы (Меркулова) и исповеди у старца-утешителя. Во время этого посещения было дано и предсказание о дальнеших испытаниях всей Царской семьи. У самодержца была внутренняя, возможно, даже не вполне ясно осознаваемая, потребность духовного общения с братией троице-сергиевских священнослужителей, который жили в своей вере и своим служении Господу тем же, чем он сам жил как глава государства. Нельзя не отметить, как точно это слово - братия - отражает глубинный характер связей государя и священнослужителей.

Через три дня после того, как Германия объявила войну России, Николай II выехал в Москву, а на обратном пути в северную столицу он внезапно решает заехать в Свято-Троицкую-Сергиеву Лавру: «В 12 1/2 nокинули Москву и поехали в Троице-Сергиевскую Лавру. На пути было затмение солниа. После молебна у раки преп. Сергия сели в поезд и на ст. Лихобориьь видели эщелон второочередной батареи», - как всегда лаконично пишет он в своем дневнике. Этот неожиданный визит в Сергиеву обитель был, конечно же, не случаен. «Внезапность» - вот ключевое слово для объяснения этого поступка и оценки состояния души самодержца, выражающее всю глубину понимания и ясности предчувствия им надвигающейся трагедии.

Архимандрит благословил Государя иконой, писанной на доске от гроба Сергия Радонежского, и вручил ее императору. Позже икону «Явления Богоматери прп. Сергию», которая всегда сопровождала царей в военных походах и была покровительницей армии во времена ведения войн с врагами России и Православной веры, передадут в Ставку Верховного Главнокомандующего ${ }^{38}$. Конечно же, нет никаких прямых доказательств взаимосвязи между двумя событиями, забытыми в невероятно сложной и богатой российской истории и особенно Первой мировой войны 1914-1917 гг. Но после передачи чудотворной иконы в Ставку была проведена невероятно успешная крупномасштабная операция русских войск на Юго-Западном фронте, получившая название «Галицийской победы», в ходе которой была полностью освобождена Галиция и почти вся Буковина... ${ }^{39}$

Известна глубокая религиозность Николая Александровича: «Вера в Бога и в свой долг Царского служения были основой всех взглядов Императора Николая II, - писал С.С. Ольденбург. - Он считал, что

\footnotetext{
38 Император Николай II и Его семья (Петергоф, сентября 1905 Екатеринбург, май 1918 г). По личным воспоминаниям П. Жильяра. Вена. Русь, 1921, стр.119-111.

39 Игумен Симеон (Гаврильчик), насельник Свято-Троицкой Сергиевой Лавры, кандидат богословия (2015 г.) Последний приезд Государя Императора Николая II Александровича, царя-мученика, в Троице-Сергиеву Лавру (К 100-летней годовщине).
} 
ответственность за судьбы России лежит на Нем, что Онотвечает за них перед престолом Всевышняго» ${ }^{40}$. Святость Николая II связана не с перенесенными им и его близкими мученической смертью, а со стремлением, пусть даже не удачным - спасти Россию, сохранить ее духовные истоки и судьбу в будущем. Не случайно он писал своей матери о стремление ради «действительного блага горяче любимой матушки России пожертвовать престолом и жизнью». ${ }^{41}$

В Лавру Николай II ездил за укреплением в этой уверенности. Это не были церемониальные поездки, хотя внешняя помпезность была обязательным ритуальным требованием. В Троице-Сергиевой лавре, с которой была связана духовная чистота и стойкость России, царь искал духовную опору в своих попытках спасти Россию от надвигающихся на нее потрясений. Время его царствования качественно/радикально отличалось от прежних периодов самодержавия. Нараставшая со второй половины XIX века десакрализация царской власти была детонатором разрушительных процессов в социальном и духовном организме империи, приведшим к исчезновению империи. Один из крупнейших современных исследователей жизни и деятельности Николая II А.А. Боханов отмечает, что благодаря влиянию «безрелигиозной «Европы» «монархический «истеблишмент» воспринимал последнего российского императора уже не как «фигуру, сакрально осененную»; и всего лишь как «правителя», наделенного «чрезмерными властными прерогативами». «В последний период Царской России эта - излюбленнейшая тема среди тех, кто называл себя «монархистами». ${ }^{42}$

Эта установка была враждебной традициям русского народа, часть которого все менее и менее понимала, что царская власть является для государства Российского «вернейшим оплотом мира, залогом счастья и благоденствия его внутреннего и величия его внешняго». ${ }^{43}$ Слова Московского митрополита Филарета, сказанные еще при короновании Николая I о том, что любовь народа к Государю и Отечеству «не столько по умозрению, сколько по чувству сердиа» является «крепительной пищей для подвигов труднейших, во времена труднейшие», «манной народной жизни», которая охраняется «высшим, совершенно небесным и Божественным законом любви христианской» ${ }^{44}$, теперь уже были почти что непонятны. Реальное историческое движение части российского общества, прежде всего, большинства ее элиты, и внероссийских сил состояло в стремлении «уничтожить православное царство».

\footnotetext{
40 См.: Ольденбург С.С..Царствование Императора Николая II, Белград, 1939.

41 Цит. по Игумен Симеон (Гаврильчик), насельник Свято-Троицкой Сергиевой Лавры, кандидат богословия (2015 г.) Последний приезд Государя Императора Николая II Александровича, царя-мученика, в Троице-Сергиеву Лавру (К 100-летней годовщине).

42 Боханов А.Н. Последний царь. М. Вече. 2006, с. 265.

43 Московския Церковныя ведомости. 1896г, №20, с. 268.

44 СТСЛ. 2009, т. 2, с. 497
}

Связь самодержца с православной верой, русской церковью и, в частности, ее наипервейшем монастырским центром - Троице-Сергиевой лаврой - этому противостояла. Но «чем больше люди отходили от Христа, - отмечает известный биограф последнего Всероссийского монарха П. Мультатули, - тем они меньше понимали Николая II в котором, как ни в ком другом, русское начало не нашло себя в такой полноте, с такой ясностью и с такой силой. В последнем Государе, как в зеркале, отразилась душа России, ее верность и любовь ко Христу, ее имперская мощь, ее голгофские муки и крестная смерть». ${ }^{45}$

«Во многом подражая и следуя примеру святого Александра Невского, Государь все свои важные дела начинал с молитвы, частого посещения храмов и молитвы во время обедни. Эти «официальные визиты» носили не номенклатурный характер, они были не просто формальным исполнением принятого придворного этикета. Они для Государя являлись чем-то вполне естественным и искренним выражением внутреннего религиозного горения христианского сердца. Поэтому оценка личности Государя, сделанная святым праведным отцом Иоанном была невероятно точна - как Государя «сияющего правой верой и благочестием $»^{46}$.

Личность Николая II, к сожалению, не понята ни современниками, ни советскими историками, а во многом и современными исследователями. Для того, чтобы осознать масштаб этой личности и глубину осознания им личной и общероссийской трагедии, необходимо не только воссоздать движущие причины и скрытые факторы его пути на Голгофу Ипатьевского дома, но и связь последнего самодержца Всея Руси с Троеце-Сергиевой лаврой, которая за почти семь столетий превратилась в опору российского царствования в сознании и рюриковичей, и Романовых. А также с ее основателем Сергием Радонежским, которого Иван Грозный называл «игуменом земли Русской». Трудно не согласиться с насельником Свято-Троицкой Сергиевой Лавры игуменом Симеоном (Гаврильчиком), который отмечает духовно-мистический смысл того факта, что кончина Царственных мучеников произошла 4 (17) июля 1918 г., в канун празднования памяти прп. Ведь по убеждению Прп. Иоанна Дамаскина, святые для почитающих их становятся ходатаями и предстателями пред Богом о спасении их души

За почти семь веков своего божьего служения народу и государству Российскому Лавра стала неким духовным двойником высшей власти в стране. Обитель, учиненная святым Сергием Радонежским, представляла Божеское начало на русской земле. Тро-

\footnotetext{
45 См.: Мультатули П. Император Николай II. Человек и монарх: «Вече», 2016.

46 Слово на день памяти святаго славнаго чудотворца Николая, архиепископа Мирликийскаго, и тезоименитства благочестивейшаго Государя Императора Николая Александровича.// Праведный Иоанн Кронштадстский. Полный годичный круг поучений. М. 1997, с.329. 47 Прп. Иоанн Дамаскин. Точное изложение православной веры. Творения. СПб, 1913, т.1. Кн.4. С. 318.
} 
ице-Сергиева Лавра служила «сердцем России» ${ }^{48}$ ее внутренним духовным центром и опорой народа в

\footnotetext{
48 Троице-Сергиева Лавра и русские государи. Выставка, аннотация. [Электронный ресурс] / Музеи России - Режим доступа: http://www. museum.ru/N7802 (дата обращения 10.07.2018).
}

тяжелейших испытаниях, выпавших на его долю за последние семь столетий. Но одновременно и местом обновления и умножения духовных сил державной власти. Лавру можно назвать самым главным и подлинным посредником между Всевышним и высшей власть в России.

\section{Библиография}

Боханов А.Н. Последний царь. М. Вече. 2006.

Вкладная книга Троице-Сергиева монастыря / Изд. подготовили: Е.Н. Клитина, Т. Н. Манушина, Т. В. Николаева. М. Наука. 1987.

Жильяр П. Николай II и его семья, Вена, 1921.

Забелин И. Троицкие походы русских царей / И. Забелин. М.: Изд. Императорского Общества истории и древностей российских. 1847.

Иларий, Арсений. М. Изд. Императорского Общества истории и древностей российских. 1878. Ч. 2. Отд. 6.

Историческое описание Свято-Троицкия Сергиевы лавры, составленное по рукописным и печатным источникам профессором А. В. Горским. 1841. Ч.1.

Лаврская летопись [электронный ресурс] / Свято-Троицкая Сергиева Лавра - Режим доступа: http://stsl.ru/history/ (дата обращения 10.07.2018).

Московския Церковныя ведомости. 1896г, №20.

Мультатули П. Император Николай II. Человек и монарх: «Вече», 2016.

О Высочайшем посещении Лавры Преподобного Сергия государем императором Александром III 22 мая 1883 г. [электронный ресрс] / Свято-Троицкая Сергиева Лавра - Режим доступа: http://stsl.ru/news/all/o-vysochayshemposeshchenii-lavry-prepodobnogo-sergiya-gosudaremimperatorom-aleksandrom-iii-22-maya (дата обращения 10.07.2018).
Ольденбург С.С. Царствование Императора Николая II, Белград, 1939.

Праведный Иоанн Кронштадстский. Полный годичный круг поучений. М. 1997.

Прп. Иоанн Дамаскин. Точное изложение православной веры. Творения. СПб, 1913, т.1. Кн.4. С. 318.

ПСРЛ. Т. VІІІ. СПб. 1859.

ПСРЛ. Т. 12. СПб. Изд. Императорской Археологической комиссии. 1901.

ПСРЛ. М. Наука. 1965. Т. 30.

ПСРЛ. - СПб. Изд. Императорской Археологической комиссии. 1904. Т. 13.

ПСРЛ. Т. 34. Постниковский, Пискаревский, Московский и Бельский летописцы. М. Наука. 1978.

СТСЛ. 2009, т. 2, 4, 1851-1857.

Троицкий поход царя Алексея Михайловича [электронный ресурс] / Православный портал «Покров», Материал подготовлен редакцией журнала «Встреча» - Режим доступа: http://pokrov.pro/troickij-poxod-caryaalekseyamixajlovicha/ (дата обращения 10.07.2018).

Троице-Сергиева Лавра и русские государи. Выставка, аннотация. [Электронный ресурс] / Музеи России - Режим доступа: http://www.museum.ru/ № 7802 (дата обращения 10.07.2018). 


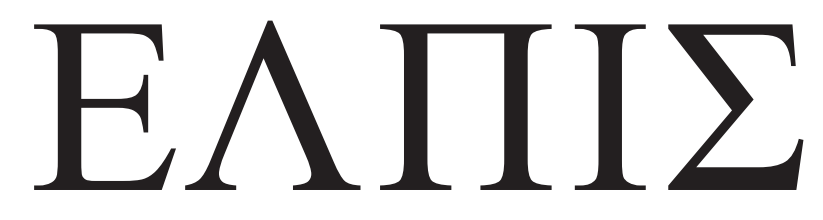

CZASOPISMO TEOLOGICZNE KATEDRY TEOLOGII PRAWOSŁAWNEJ UNIWERSYTETU W BIAŁYMSTOKU

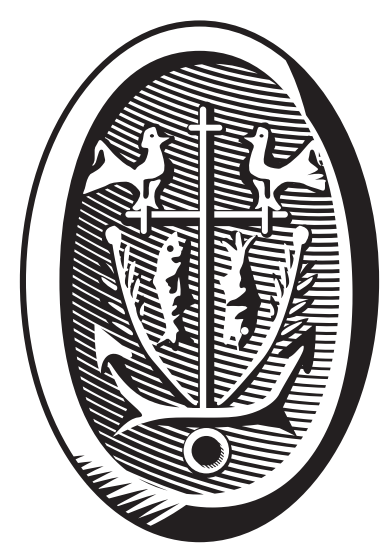

ADRES REDAKCJI

ul. Ludwika Zamenhofa 15, 15-435 Białystok, Polska tel. 85 745-77-80, e-mail: elpis@uwb.edu.pl www.elpis.uwb.edu.pl 